\title{
Primary Lung Lymphoma
}

\author{
Mesiha Babalık, Abdullah Şimşek, İlhami Yapıcı \\ Clinic of Chest Diseases, Prof. Dr. Türkan Akyol Chest Diseases Hospital, Bursa, Turkey
}

\begin{abstract}
Primary lung lymphoma (PLL) is a rare entity. It is difficult to diagnose, with a nonspecific clinical and radiological presentation. It may masquerade as pneumonia and lung tumors, and this disease should be kept in mind especially in the differential diagnosis of nonresolving pneumonias. This report describes a PLL case.

Keywords: Diagnosis, lung, primary lymphoma
\end{abstract}

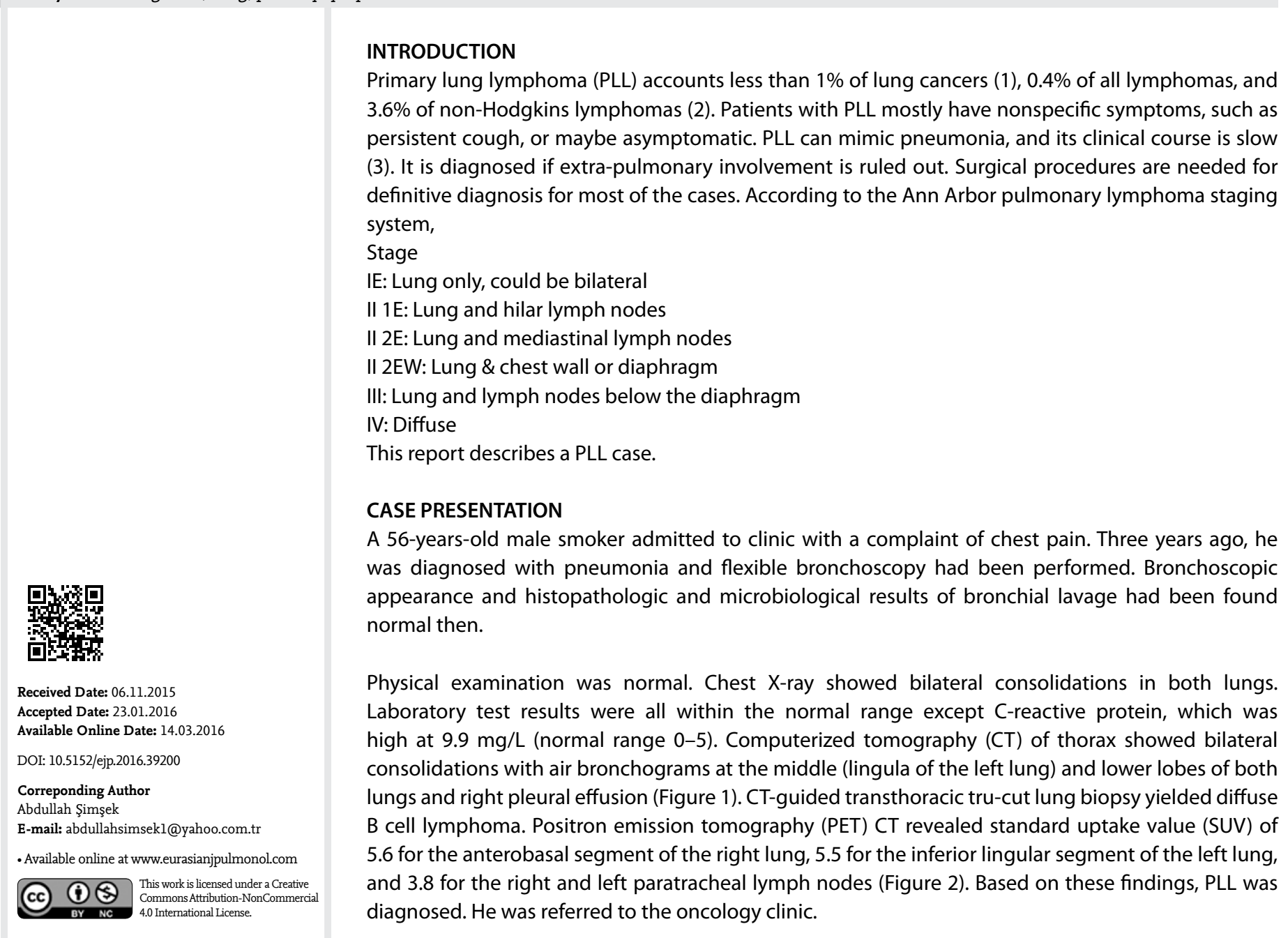




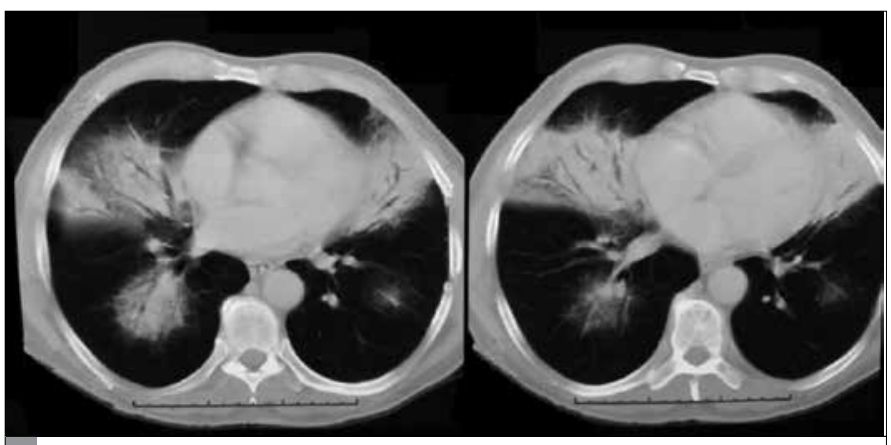

Figure 1. Thorax CT: Bilateral consolidations with airbronchograms CT: computed tomography

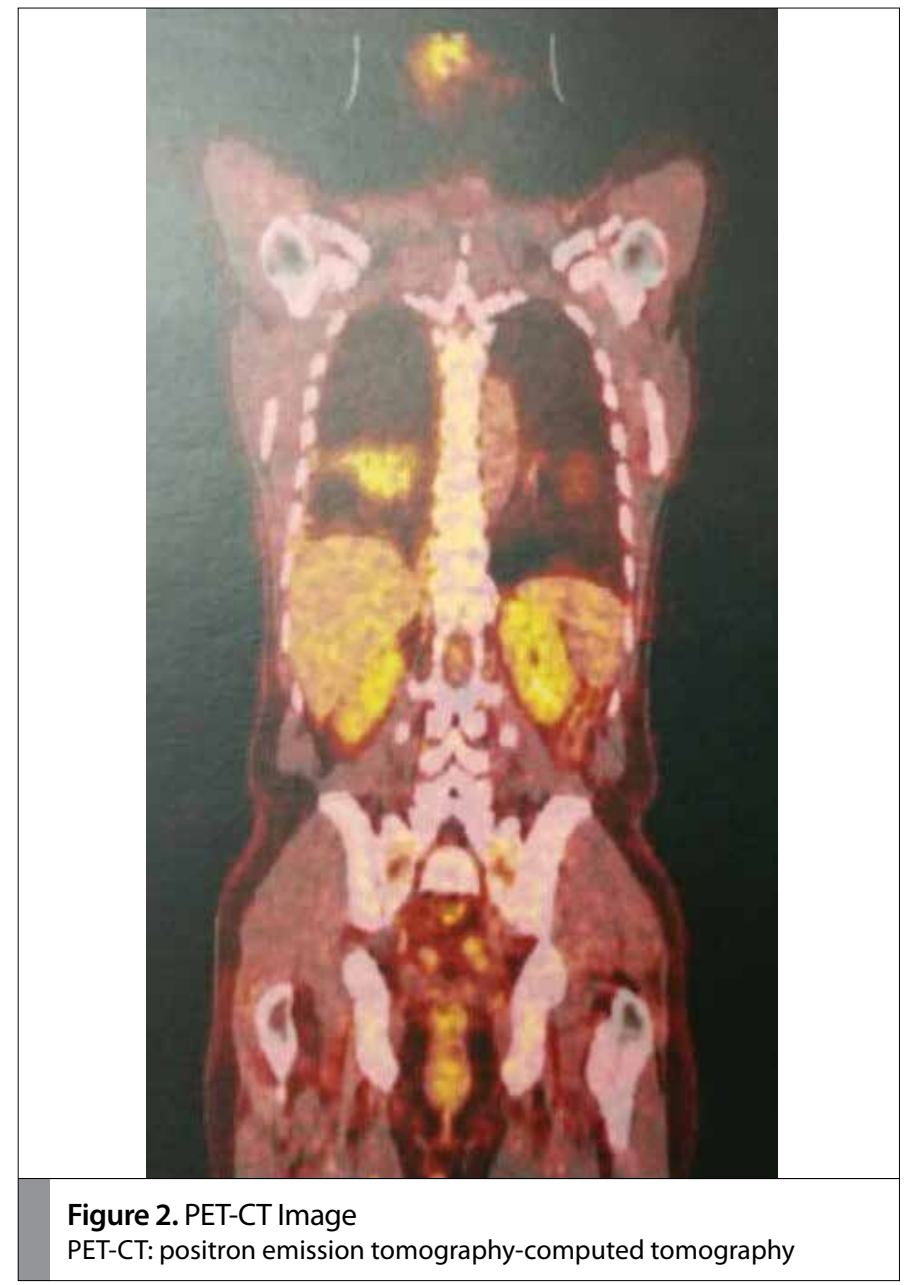

\section{DISCUSSION}

The most frequent type of PLL is mucosa-associated lymphoid tissue lymphoma accounting for $58-87 \%$ of cases, but diffuse large B-cell lymphoma accounts for $5-20 \%$ of cases $(4,5)$.

Characteristics of the PLL are as follows: 1) Difficult to diagnose, with a nonspecific clinical and radiological presentation; 2) Diagnostic yield is low; 3) Difficult to differentiate from pseudo-lymphomas; and 4) Outcome is good. PLL is commonly seen in the fifth decade followed by late sixth and seventh decades of life. There is no extrapulmonary involvement in PLL, but hilar or mediastinal lymph node involvement or chest wall involvement can be seen (6). In our patient, there was bilateral involvement of the lung with mediastinal lymph node involvement. PET-CT showed no extra-pulmonary involvement.

Primary lung lymphoma may masquerade as pneumonia and lung tumors. It generally follows an indolent and slow clinical course and is detected incidentally on radiograms. Similarly, our patient had been misdiagnosed as pneumonia 3 years ago.

Radiographic findings of PLL are not specific, but the typical presentations are single or multiple nodular infiltrations involving one or both lungs; these infiltrations frequently have air bronchograms $(1,7)$. Nodal involvement is seen in $30 \%$ of the cases. Pleural effusions have been found in $25 \%$ of the cases. Atelectasis is rare. In our patient, there were bilateral consolidations with air bronchograms and pleural effusion.

It has been shown that $66.7 \%$ of the patients required surgical procedures to establish the definitive diagnosis. Bronchoscopy in $83 \%$ revealed the disease, but transbronchial lung biopsy was useful only in $30 \%$ of the patients (8). In the present case, diagnosis of PLL was confirmed by CT-guided transthoracic tru-cut lung biopsy.

According to Ann Arbor staging system, the present case was stage II $2 \mathrm{E}$.

The prognostic factors are not well defined. The prognostic value of the hilar or mediastinal node involvement is controversial $(9,10)$. Higher stage disease was associated with a significantly worse outcome according to Graham et al. (1). However, it was suggested that bilateral disease was the most important prognostic factor. In the majority of cases, surgery may be used followed by chemotherapy. PLL has a good prognosis and a recurrence rate of less than $50 \%(1)$.

\section{CONCLUSION}

Primary lung lymphoma is a rare entity; when bilateral pulmonary lesions are seen with a nonspecific clinical presentation, physicians should consider PLL in the differential diagnosis.

Informed Consent: We could not reach or communicate with them because of incorrect telephone number patient gave us. So written/verbal informed consent could not be obtained from the patient or parents of patient.

Peer-review: Externally peer-reviewed.

Author Contributions: Concept - M.B.; Design - A.Ş., M.B.; Supervision - A.Ş., I.Y.; Materials - I.Y.; Data Collection and/or Processing - M.B., A.Ş.; Analysis and/ or Interpretation - A.Ş., I.Y.; Literature Search - I.Y., A.Ş.; Writing Manuscript A.Ş.; Critical Review - A.Ş., M.B.

Conflict of Interest: No conflict of interest was declared by the authors.

Financial Disclosure: The authors declared that this study has received no financial support.

\section{REFERENCES}

1. Graham BB, Mathisen DJ, Mark EJ, Takvorian RW. Primary pulmonary lymphoma. Ann Thorac Surg 2005; 80: 1248-53. [CrossRef]

2. Rosenberg SA, Diamond HD, Jaslowitz B, Craver LF. Lymphosarcoma: a review of 1269 cases. Medicine 1961; 40: 31-84. [CrossRef]

3. Ünsal İ, Anar C, Yılmaz U, Halilçolar H, Kargı A, Pişkin Ö. Primary Pulmonary Lymphoma (BALT Lymphoma): A Case report. Turk Thorac J 2010; 11: 80-3. [CrossRef] 
4. Cadranel J, Wislez M, Antoine M. Primary pulmonary lymphoma. Eur Respir J 2002; 20: 750-62. [CrossRef]

5. Matsumoto $\mathrm{T}$, Otsuka K, Funayama $\mathrm{Y}$, Imai $\mathrm{Y}$, Tomii K. Primary pulmonary lymphoma mimicking a refractory lung abscess: A case report. Oncol Lett 2015; 9: 1575-8. [CrossRef]

6. Saltzstein SL. Pulmonary malignant lymphomas and pseudolymphomas: Classification, therapy and prognosis. Cancer 1963; 16: 928-55. [CrossRef]

7. Chua SC, Rozalli FI, O'Connor SR. Imaging features of primary extranodal lymphomas. Clin Radiol 2009; 64: 574-88. [CrossRef]
8. Zinzani PL, Tani M, Gabriele A, Poletti V, Stefoni V, Alinari L, et al. Extranodal marginal zone B-cell lymphoma of MALT-type of the lung: single-center experience with 12 patients. Leuk Lymphoma. 2003; 44: 821-4. [CrossRef]

9. Ferraro P, Trastek V, Adlakha H, Deschamps C, Allen MS, Pairolero P. Primary non Hodgkins lymphoma of the lung. Ann Thorac Surg 2000; 69: 993-7. [CrossRef]

10. Hu YH, Hsiao LT, Yang CF, Chiou TJ, Liu JH, Gau JP, et al. Prognostic factors of Chinese patients with primary pulmonary non-Hodgkins lymphoma: the single-institude experience in Taiwan. Ann Hematol 2009; 88: 83946. [CrossRef] 